\title{
Practices of the Seasonal Migrant Workers' Children in Play
}

\author{
Müge Artar \\ Faculty of Educational Sciences, Ankara University, Ankara, Turkey \\ Email: atacan99@hotmail.com
}

Received 1 September 2014; revised 19 September 2014; accepted 25 September 2014

Copyright (C) 2014 by author and Scientific Research Publishing Inc.

This work is licensed under the Creative Commons Attribution International License (CC BY). http://creativecommons.org/licenses/by/4.0/

(c) (i) Open Access

\section{Abstract}

Seasonal migrant and temporary agricultural labour is a form of employment emerging in the process of labour-intensive farming. Both academic studies and surveys conducted by various national/international organizations tried to address different dimensions and problem areas of the issue. They mostly focus on working and living conditions of the workers and child/female labour in these works. Still, these studies rarely focus specifically on the state of children aged 0 - 6 years in their early living and working environments. Throughout the period in which their families are engaged in seasonal works, these children share the same environment with adults, face same risks and receive no special care or attention. Given these facts, the objective of the study is stated as follows: "Exposing, through scientific methods, social, cognitive and developmental problems of 0 - 6-year-old children of families engaged in migrant-seasonal agricultural work of labour-intensive character and developing social policy suggestions for improving their life quality on the basis of findings to be obtained." Within this framework, 7 to 10 days long field surveys were conducted with the participation of researchers from different disciplines in provinces and districts in order to conduct in situ observations on children aged 0 - 6 years. Participatory observation is adopted as the basic method in this survey. They mostly play with sand, inventing games by loading and unloading sand from a vessel or shaping it in some way. In two-child games children play together or parallel games. Also, gender preference is absent in this age group while choosing playing partners.

\section{Keywords}

Seasonal Migrant Workers, Play, Social Development, Cognitive Development

\section{Introduction}

Today the nature children's play has been changing all around the world. This change seems to exist in the qual- 
ity of play, categories of play and site of play. Play has been changing in their qualities and it seems work play is taking place of free play. Social factors like industrialized urbanization and over population remove the basic characteristics such as "instinctly motivated", "free chosen", "active participation”. Children's play in outdoors, in gardens, streets which are in the rural world tend to disappear (Meisels, 1992; Nielson \& Monson, 1996).

Kinds of play are being changed. Plays such as computer games appeared which diminishes the importance of playmate. Site of play is also changing children's tendency to play indoors rather than outdoors (Spodek, 1988).

It has long been known that play has an important role on children's cognitive, emotional, social, and physical development. Play, not only as a joyful activity, but it takes place as a function in cognitive, emotional and social development in children's lives. On one hand, child learns the roles and the rules of adult world; on the other hand, he/she has the opportunity to try and expand his/her cognitive capacity. If play is so important in children's lives, researchers must distinguish the characteristics of play from other behaviours (Walsh, 1989). Also it must find its place in the educational programs not only in kindergartens, in elementary schools as well. A basic understanding within the field of early childhood development is that young children learn through play and that play has value for development (Chafel, 1987). Accordingly, a rationale is provided for preschool programs to include some form of free-play period during their own activities from various available options. However, according to Elkind (1973), the amount and the type of play activity to be encouraged are less well understood and are issues related to the instruction versus enrichment controversy in early childhood education (Johnson et al., 1980). Despite evidence to support the importance of play in child care programs, parents and teachers question the importance of play in curriculum, the extend of time allotted to free play, or the absence of more "academically oriented" activities in many preschool and child care programs (Bloch \& Choi, 1990).

Seasonal migrant and temporary agricultural labour is a form of employment emerging in the process of labour-intensive farming. Both academic studies and surveys conducted by various national/international organizations tried to address different dimensions and problem areas of the issue. They mostly focus on working and living conditions of the workers and child/female labour in these works (Y1ldırak et al., 2002). Still, these studies rarely focus specifically on the state of children aged 0 - 6 years in their early living and working environments. Migrant agricultural labour involves short-term migration from permanent settlements to regions and areas where labour intensive farming is prevalent. It makes it necessary to remain for a period time (mostly until jobs undertaken are completed) in migrated areas. In certain cases families taking part in migration may move to two or more different places for different crops depending upon climate and time of the year. The areas where migrant workers will work as well as their working conditions are determined by agricultural intermediaries who are called "elçi" or "dayıbaş" locally. As such, agricultural workers mostly have no word to say concerning their working locations and conditions. Temporary labour is mainly working on daily basis and workers involved actually live in or quite close to their working places. The case of participating to migration with all family members is observed predominantly in migrant-seasonal agricultural works. Particularly in such agricultural works as harvesting, all family workers capable to work are involved in order to maximize family income. The main target group of the survey consists of migrant-seasonal agricultural workers. There are three leading actors involved in seasonal agricultural works: Employers, workers and intermediaries. Employers may be landholders and agricultural companies that employ seasonal workers. Employers other than companies are mostly family enterprises and these enterprises vary with respect to size, type of crop and geographical characteristics of the area. Intermediaries are the most important actors in the system of seasonal agricultural employment. The main functions of "elçi" or "dayıbaşı" as they are called locally is to act as a bridge between employers and workers which can also be put as "making sure 'demand finds its supply'”. Intermediaries in agricultural works are the main organizers in the system and according to regulations on finding jobs and workers in agriculture issued in the 70s their performance is to be supervised. In spite of this legislation, however, things go through face to face and informal contacts and relations. Agricultural intermediaries bargain with employers on many issues concerning living and working conditions. Kinship relations between intermediaries and workers they mobilise are widely observed. As will be explained in detail later, agricultural workers mostly consist of rural and urban poor. For workers involved in agricultural works for a long time, it can be said that village/rural sector attachment is minimized in our days and particularly in South-Eastern Anatolia agricultural workers actually live in city centres. These people work without any social security coverage at all. In earlier studies, this form of employment was described as an additional work through which subsistence farmers who cannot sustain themselves solely with their plots try to increase their family income. Today, on the other hand, it is the main source of income for many agricultural workers. 
Throughout the period in which their families are engaged in seasonal works, these children share the same environment with adults, face same risks and receive no special care or attention. Starting from the 80s various studies have been conducted on seasonal agricultural employment. Both academic studies and surveys conducted by various national/international organizations tried to address different dimensions and problem areas of the issue (Ertürk, 1994; Genelge, 2014). These studies and surveys mostly focus on working and living conditions of agricultural workers and child/female labour in these works. There are also, however, other studies examining the living and working conditions of workers from the perspective of public health. Still, these studies rarely focus specifically on the state of children aged 0 - 6 years in their early living and working environments.

Early years of childhood present many opportunities for development and growth while posing serious risks at the same time. In this period, health, nutrition, growth and social-emotional needs of the child have to be met. In children whose needs in early period are met satisfactorily, health problems, class repetition and rates of delinquency are reduced and children perform better both in their schools and production in their later life. Similarly, mothers enjoying support in the development of their children live better and more productively, continue their education and take part in working life. Safeguarding the right of the child to growth and development is the best way to reduce income and gender-based inequalities and ensure national economic development. With their behaviour, feelings and thinking as well as developmental characteristics, children are different from adults; they are quite unique and receptive human beings open to change and innovation. For this, it is essential that they are provided stimuli in their early years as well as quality education and good educational environments.

According to studies, 50\% of all mental development up to age 17 takes place in the age interval $0-4$ and $30 \%$ in the interval $4-8$. And $33 \%$ of school success up to age 18 is attributable to education received at ages 0 to 6 (Tekiner, 1996: p. 10). Throughout the period in which their families are engaged in seasonal works, these children share the same environment with adults, face same risks and receive no special care or attention. As such, their developmental processes are different than their peers (reserving for class differences). Adding to these the poverty of their families, the living standards of children examined in this study are quite unfavourable. Given these facts, the objective of the study is stated as follows:

"Exposing, through scientific methods, social, cognitive and developmental problems of 0 - 6-year-old children of families engaged in migrant-seasonal agricultural work of labour-intensive character and developing social policy suggestions for improving their life quality on the basis of findings to be obtained."

Within this framework, 7 to 10-day-long field surveys were conducted with the participation of researchers from different disciplines in provinces and districts listed below in order to conduct in situ observations on children aged 0 - 6 years.

$\begin{array}{ll}\text { Province } & \text { Month } \\ \text { Ankara-Polatlı (I) } & \text { October 2009 } \\ \text { Adana-Karataş } & \text { July 2010 } \\ \text { Yozgat-Boğazlayan } & \text { September 2010 } \\ \text { Ankara-Polatlı (II) } & \text { October 2010 } \\ \text { Şanlıurfa (I) } & \text { December 2010 } \\ \text { Şanlıurfa (II) } & \text { February 2011 }\end{array}$

\section{Methodology}

In its shortest definition, research is an initiative taken to respond systematically and logically to a specific question or a set of questions. While working, a researcher strives to explore and identify the unexplored and to reach certain conclusions. For this, the researcher collects information that can respond to the question or questions framing the investigation, interprets this information and draws conclusions (Y1ldirım, 1999). One of the methods employed by a researcher in conducting this work is qualitative survey approach. The emergence of this approach dates back to early 20th century. First examples of qualitative survey were in the fields of anthropology and sociology whereby field surveys were conducted to examine the social and cultural structure of human life in natural environments (Bogdan \& Biklen, 1992). One of the most significant examples of this kind of work was given in the early 20th century by Margaret Mead, a 24-year-old new university graduate who left Philadelphia for an 8 month-long participatory observation on the people of Samoa whose culture was then unknown to the west. It was a groundbreaking event upon which western societies started to question their established norms on child-raising and gender roles in society (Pollard, 1992). With reference to its characteristics, qualitative 
survey is coined differently as "natural survey”, "interpretative survey” or "field survey”. According to Lincoln and Denzin (cited by Işıkoğlu, 2005), a qualitative survey is one that approaches its topic of research in an interpretative and natural way and focuses on more than one method. Yıldırım and Şimşek (2004) define qualitative survey as a research that employs methods of qualitative data collection such as observation, interview and document analysis and follows a qualitative path geared to exposing perceptions and events in a holistic manner in their natural environments.

Ethnographic methods basically include the method of participatory observation. In this method, the researcher directly participates in community life; learns about the realities of people directly from them by talking and observing. There may be varieties of this method depending upon the level of participation to observation: Full participation, participating as observer and observing as participant. Hammersly and Atkinson maintain that the quality of information collected through one of two extremes may remain limited and the difference between the other two methods is questionable. The ideal approach should be the one which minimizes the effect of researcher on target population and increases the depth of information collected. This method can be chosen from a wide range extending observation from a hidden point to researcher acting as an active participant.

\section{Play Observation Form and Conclusions}

The play observation form is a comprehensive one that field workers fill in while observing plays, playing materials, social interaction emerging during plays and cognitive guidance given to children by their mothers while playing.

For children in the age group 0 - 2, play and toy consists of mother or any other child/adult around at that moment. While held by their mothers, majority of children try to play with whatever object their mothers hold, part of dresses or any other object they may grab. There are not many children who have their toys. Those who have are mostly the children of younger couples and young couples can be found only in few tents. Children play with whatever they find around, which include tea spoons, plates or even medicine boxes. Children younger than Age 2 are not allowed to go farther than close surrounding of tents. If they have to, they are accompanied or carried by their elder siblings. Children in this age group who can walk are observed to play with two types of toys. The first group consists of small household items including bread board, cups and pans while the second group comprises more hazardous items like boxes of medicine. Another notable feature is that there is a salient gender dimension in children's playing. While playing with small household items is common to both small girls and boys, the way of playing with these items is differs in terms of gender roles. It is an apparent feature that girls play games that have connections to women's gender roles. The situation seems, somewhat different for male children. They use small household items in a way not reminiscent of mothers' role; however, they display no behaviour pattern that can be strictly attributed to male gender roles. This can be explained by the fact that fathers are away from tents for 12 - 14 hours a day making it less likely for children to observe male gender roles.

Children in this age group play with whatever they find around. Their range of mobility is quite wide and they act independently. They have the chance of playing with everything existing around tents. These "toys" can be big bread knives, boxes of insecticides, pieces of broken glass or tomatoes and melons kept in sacks around. While girls play what is called "symbolic games males" are engaged in running-chasing type games.

They mostly play with sand, inventing games by loading and unloading sand from a vessel or shaping it in some way. In two-child games children play together or parallel games. Also, gender preference is absent in this age group while choosing playing partners. To examine the forms in which children play, the survey team video recorded children while playing. Large majority of 32 visual materials examined consist of games of pushing one another around while smaller children (Age 3 - 6) watch them without taking part and run after their elders.

There are only 11 visual materials showing children Aged 2 - 6 while they played. Only 3 of them are visuals showing 3 - 5 children together, but engaged in parallel activities rather than playing as a group. In these visuals children can be observed while playing with sand and occasionally as engaged in pretend play (making circles, simulating eating, etc.). As far as playing and toys are concerned, children in this age group are able to create their own styles and objects. Toys include balls, kite, pieces of metal pipe, etc. In short, all objects found around which seems interesting and unfamiliar may be used as toys.

4 - 6-year-old children are relatively more independent. Since they spend a lot of time out of tents, any object 
they find around may be a toy in their games. Toys in proper sense are seen seldom. Running-chasing is the most favourite game. Children at these ages may be observed pushing and hitting each other, one is running and the other is chasing after.

Games played by girls are mostly those accompanied by singing including simulations of dining and homemaking as well as playing with water and mud. There are cases they imitate celebrity singers with their elder sisters. Children especially enjoy, as a game, running after and hanging to bypassing trucks. This very dangerous "game" is taken by children as a special amusement.

We often observed a certain game which they called as BELT GAME... This game is frequently played by male children. Here, belt is a tool of penalty whereby a failing player is slapped with belt. It is a kind of hidingfinding game. The belt is hidden somewhere and if not found one of the players slaps the others not being able to find it. Games played by male children also include, "oily belt" ("hot or cold"), wrestling on the ground, jumping down from a 1.5-metre-high sand hill, ball games, sling shooting, hide-and-seek, etc.

Agricultural workers prefer having too many children. Families have 8 children on average and birth intervals are too short, around one year. When the team first arrived to the survey area, many children surrounded the team with curious eyes and the first thing noticed in this encounter was that children other than those in the age group 0 - 2 looked physically quite younger than their age. For example, Hacer whose father said she was 6 years old and later her mother corrected as 5 looked only 2 - 3 years old. Other physical characteristics observed include underweight, thin neck, narrow shoulders, sunk-in eyes and protuberant cheekbone.

It is quite difficult for some fathers to tell the names and ages of their children. The rationale behind having so many children seems to be economic in the first place. As stated earlier, exploitation of child labour is in serious dimensions and each newborn child is considered as an economic asset in this sense. Children are not made with the expectation of having them build an occupation for themselves. Families are well aware that such expectations would not be realistic given their present life conditions. Seasonal agricultural employment is seen as the destiny of all coming generations; people cannot think of any other future for their children, within the next ten years for instance, than agricultural employment and present living conditions. That is why, within these conditions seasonal migrant workers never look play as an important fact for their children to grow. The only time that they were playing freely is the time that their family members went to work but this time they were faced with many more risks because they were lest at the filed unattended.

\section{References}

Bloch, M. N., \& Choi, S. (1990). Conceptions of Play in the History of Early Childhood Education. Child and Youth Care Quarterly, 19, 31-47. http://dx.doi.org/10.1007/BF01085553

Bogdan, R. C., \& Biklen, S. K. (1992). Qualitative Research for Education: An Introduction to Theory and Methods. Boston: Allyn and Bacon.

Chafel, J. A. (1987). Developmental Processes and Policy Implications. Child and Youth Care Forum, 20.

Ertürk, Y. (1994). Kirsal Dönüşümve Hanehalki Gücü Kullanım Biçimleri, Tarım Haftası 94 Sempozyumu. Ankara: ZiraatBankası Kültür Yayınları.

Genelge (2014). Mevsimlik GeziciTarım İşçilerinin Çalışmave Sosyal Hayatlarının İyileştirilmesi. http://www.csgb.gov.tr/csgbPortal/ShowProperty/WLP\%20Repository/csgb/slogan/dosyalar/dokuman3

Johnson, J. E., Ershler, J., \& Bell, C. (1980). Play Behavior in Discovery-Based and a Formal Education Preschool Program. Child Development, 51, 271-274. http://dx.doi.org/10.2307/1129621

Meisels, S. J. (1992). Doing Harm by Doing Good: Latrogenic Effects of Early Childhood Enrollment and Promotion Policies. Early Childhood Research Quarterly, 7, 155-174. http://dx.doi.org/10.1016/0885-2006(92)90002-G

Nielson, D. C., \& Monson, D. L. (1996). Effects of Literacy Environment on Literacy Development of Kindergarten Children. The Journal of Educational Research, 89, 259-271. http://dx.doi.org/10.1080/00220671.1996.9941327

Tekiner, Ö. (1997). Okulöncesi eğitiminde yeni yaklaşımlar. Okulöncesi Eğitim Sempozyumu (30-31 Mayıs 1996, Ankara). Ankara: Ankara Üniversitesi Basımevi.

Walsh, D. J. (1989). Changes in Kindergarten: Why Here? Why Now? Early Childhood Research Quarterly, 4.

Yıldırak, N., Gülçubuk, B., Gün S., Olhan, E., \& Kılıç, M. (2002). Türkiye’de Gezicive Geçici Kadın Tarım İşçilerinin Çalışmave Yaşam Koşullarıve Sorunları. Uluslararası Çalışma Örgütü Türkiye Temsilciliği. www.ilo.org/public/turkish/region/eurpro/ankara/publ/kadintarim.pdf

Yıldırım, A. (1999). Nitel Araştırma Yöntemlerinin Temel Özelliklerive Eğitim Araştırmalarındaki Yerive Önemi (Qualita- 
tive Research Methods: Basic Characteristics and Implications for Educational Research). Eğitimve Bilim Dergisi, 2, 5879.

Yıldırım, A., \& Şimşek, H. (2004). Sosyal Bilimlerde Nitel Araştırma Yöntemleri (Research Methods in Social Sciences). Ankara: Seçkin Yayıncılık. 
Scientific Research Publishing (SCIRP) is one of the largest Open Access journal publishers. It is currently publishing more than 200 open access, online, peer-reviewed journals covering a wide range of academic disciplines. SCIRP serves the worldwide academic communities and contributes to the progress and application of science with its publication.

Other selected journals from SCIRP are listed as below. Submit your manuscript to us via either submit@scirp.org or Online Submission Portal.
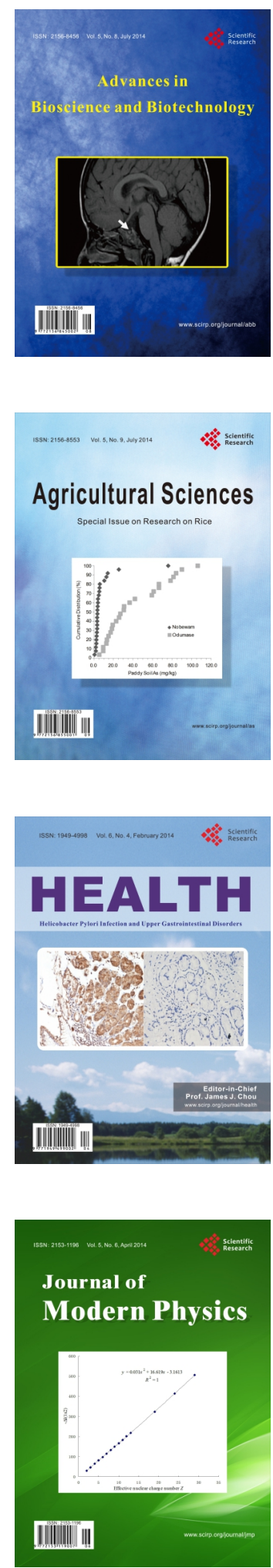
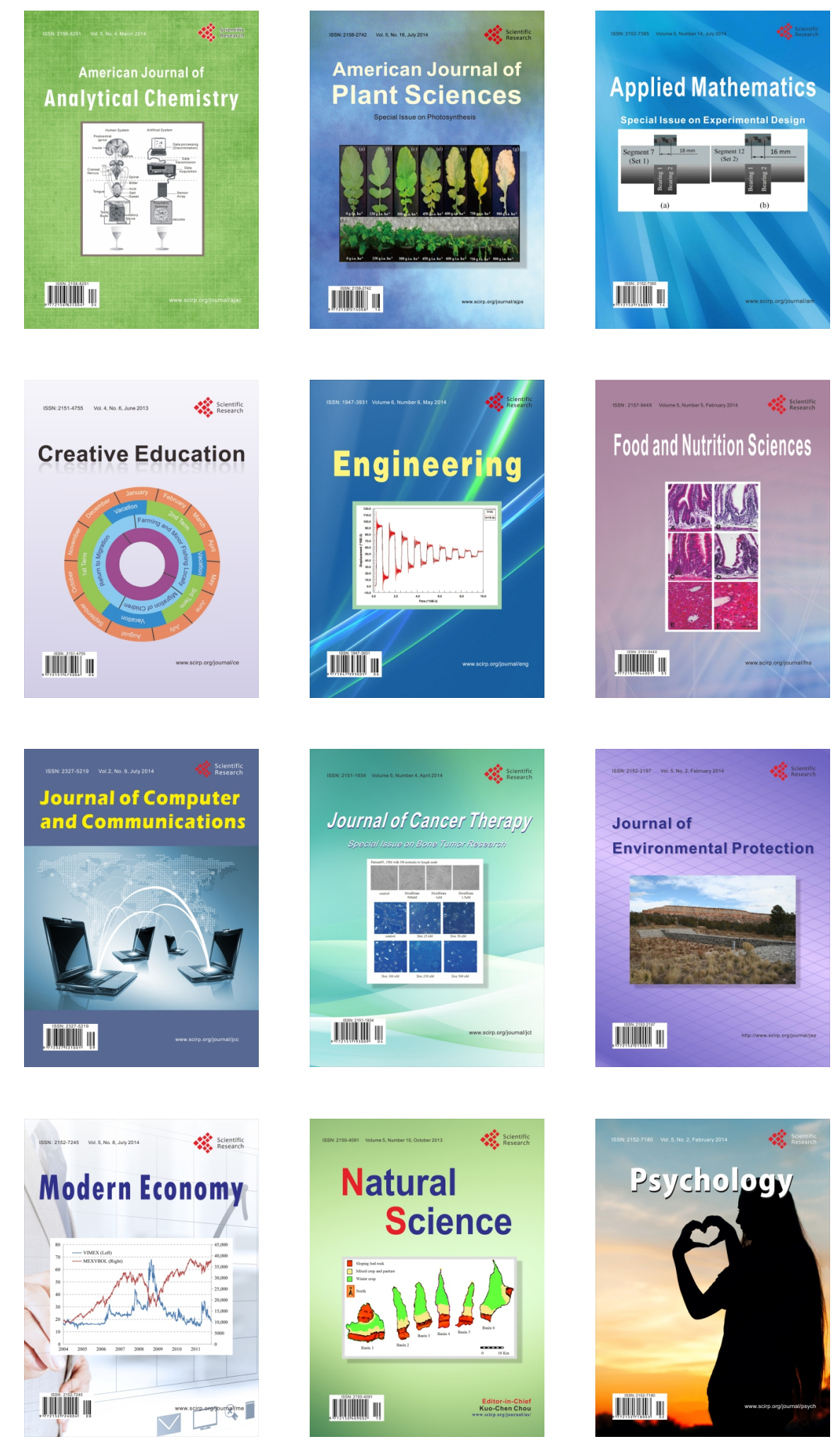